\title{
Technology and local wisdom: The Maya soil classification app
}

\author{
David J. Palma-López, Francisco Bautista
}

\section{David J. Palma-López}

Colegio de Postgraduados, Campus Tabasco, Periférico Carlos A. Molina km 3.5, Heroica Cárdenas, 86500 Tabasco, Mexico.

\section{Francisco Bautista}

leptosol@ciga.unam.mx

Centro de Investigaciones en Geografía

Ambiental, Universidad Nacional Autónoma de México. Antigua carretera a Pátzcuaro SN, Morelia, 58190 Michoacán, Mexico.

\begin{abstract}
The Maya knowledge of soils has overcome the mistrust of soil scientist towards local and indigenous knowledge because it is a classification system with hierarchically organized concepts. With the aim of popularizing and improving Maya soil knowledge, we developed the Maya soil classification app. The app includes the description of Maya soil classes and of three Maya ecological terms (Petén, Kankabal, and A'kalche') that associate the physical and biotic environments. The app includes photographs of soil profiles with their corresponding Maya terms and international classifications, along with a Maya soil classification map of the Mexican state of Yucatán showing the geographical location of Maya soil classes. Trough GPS services, the user can identify in the app the associations within local Maya soil classes. In this article we describe the structure and function of the app.
\end{abstract}

Keywords: soil knowledge, Ethnopedology, Maya knowledge, Yucatán, soil classes.
BOL. SOC. GEOL. MEX. 2019

VOL. 71 NO. 2

P. $249-260$

http://dx.doi.org/10.18268/BSGM2019v7 ln2a2

\section{RESUMEN}

El conocimiento maya sobre los suelos ha superado la desconfianza de los edafólogos hacia el conocimiento indígena puesto que es un sistema de clasificación con conceptos organizados jerárquicamente. Con el propósito de difundir y mejorar el conocimiento tradicional, desarrollamos la app clasificación maya de suelos. Esta app incluye tanto la descripción del suelo maya, como de tres de sus términos ecológicos (Petén, Kankabal y A'kalche) que vinculan el medio ambiente fisico y biótico. La app incluye fotografias del perfil del suelo con su correspondiente denominación maya y clasificación del sistema internacional, además de un mapa de la clasificación maya de suelo en el estado mexicano de Yucatán. Este artículo se describen la estructura y el funcionamiento de la app.

Palabras clave: conocimiento del suelo, Etnopedología, conocimiento Maya, Yucatán, tipos de suelo. 


\section{Introduction}

The Maya knowledge about soils is free from the limitations reported by the international agronomic and soil science community (Ettema, 1994; Krasilnikov and Tabor, 2003; Duch, 2005). The main limitations, and arguments against, include the following: a) Traditional farmers only pay attention to the soil surface layer (Ettema, 1994; Krasilnikov and Tabor, 2003). This is not true for Maya soil knowledge, as shown by the name Kankab, meaning "yellow under," that explicitly refers to the subsurface B horizon (Bautista and Zinck, 2010); b) Local soil names are difficult to organize within a soil classification system (Krasilnikov and Tabor, 2003; Duch, 2005). Yet the local soil names of the Maya easily fit into a sweeping soil classification system (Bautista and Zinck, 2010); and c) Indigenous knowledge is limited to the area in which it was developed (Ettema, 1994; Krasilnikov and Tabor, 2003). Maya soil knowledge covers the whole of the Yucatán Peninsula and probably includes Central America (Bautista et al., 2010), and other tropical regions with karst.

In addition, there is a consensus regarding the practical utility of traditional, local, indigenous, and farmers' knowledge for promoting the development of agriculture, forestry, and animal husbandry, serving as an effective communication channel between farmers and technicians (Ettema, 1994; Krasilnikov and Tabor, 2003; Duch, 2005; Ortiz et al., 2005). Our research on the Maya soil classification resulted in a better understanding of the terms, including the meaning of soil classes. We made this improved understanding of Maya traditional wisdom available to the public through a series of presentations and publications, as well as by means of electronic devices. The latter included the development of an app about Maya soil classification.

\section{Materials and methods}

A map of Maya soil classification was made using the World Reference Base (WRB) soil map for the Mexican state of Yucatán (Bautista et al., 2015) and replacing WRB soil groups with the Maya soil classes (Bautista et al., 2012). In this way, the app contains two maps, one technical with the soil groups according to the WRB and another with the Maya soil classes. When the user activates the GPS of the mobile phone, the app shows the selected map on the site where it is located. The descriptions in the Maya soil classification reported by Bautista and Zinck (2010) were improved in the app by including information previously reported in Bautista et al. (2003, 2004, 2005a, 2005b) (Pool and Hernández, 1987; Duch, 2005; Sweetwood, 2008; Bautista and Palacio, 2012). Horizon designations followed the WRB (IUSS Working Group WRB, 2015).

The app was developed using the Mobile-D method for mobile devices in five phases (Balaguera, 2013):

a) The Exploration Phase, in which an interdisciplinary workgroup was formed, including computational science engineers, soil scientists familiarized with the Maya soil classification, and geographers. The requirements and functionalities of the app were established according to the following desirable characteristics: the app should display the description of the Maya soil classes in a sequential order and in a similar way to the description used by the WRB soil classification; also, it must include images of the soil profiles accompanied by a descriptive text; finally, it must locate the user and send a message indicating the soil associated with that location.

b) The Initiation Phase, where the necessary tools for developing the desired functionalities were defined including: Android Studio as a pro- 


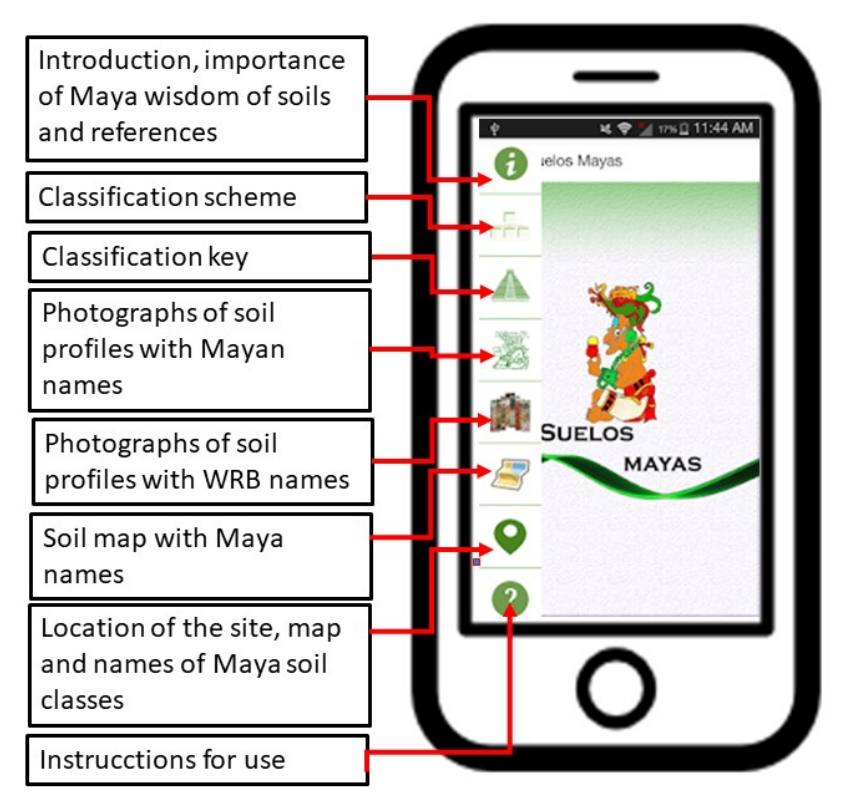

Figure 1 Functions of the app.

gramming IDE, Google Maps for user localization and for displaying the Maya soil classification, and ArcMap for processing shapefiles of the Maya soil classification map. The initiation phase also involved planning the subsequent four phases assigning four weeks to the production phase, one week to the stabilization phase, and one week to each of the validation tests.

c) The Production Phase, which was cyclically performed until the following functionalities were developed: an information display; a classification scheme; a menu with the description of Maya soil classes; twenty-one images illustrating soil profiles were compiled and edited; an option to display the Maya soil classification map; source code interacting with the mobile device GPS was created to locate the user using Google Maps services; and a help menu was developed describing the app functions in a sliding interface.

The map was made by extracting ninety-four polygons from the original map shapefiles using ArcMap; the polygons were afterwards converted to .xml files and read as type point files by the app's source code, which plotted them on the Google Maps map.

d) Stabilization Phase, in which the final integration actions were performed by assigning the app an access key to the Google Maps service, creating the interfaces for 7 and 10 inches devices, and generating the installation .apk (Canos et al., 2003).

e) System Testing Phase, in which the first stable version (1.0) was published in Play Store for validation tests. Based on the results of the validating tests, images of soil profiles were modified by adding depth and a terms section. Subsequently, version 2.0 was published and, after a validation phase, markers were added to the Maya soil classification map indicating the soil class to which each polygon belongs. The release version is 3.0.

Two free-access tools were used for developing the app: the SDK software development kit for Android; and Android Studio, an integrated development environment.

\section{Results and discussion}

\subsection{APP FUNCTIONS}

The app has eight functions: general information, the Maya soil classification scheme, the dichotomous key for soil classification, soil profile photographs with the corresponding Maya and WRB soil classification, soil map with legends (Maya soil classification and WRB), location of the work site (only in Yucatán state), and identification of the soils on the map (Figure 1).

\subsection{MAYAN SOIL GLASSIFICATION SYSTEM, A PROPOSAL}

The twenty-one Maya soil classes were encode based on the WRB soil groups (Figure 2). The Maya soil classes are described according to di- 


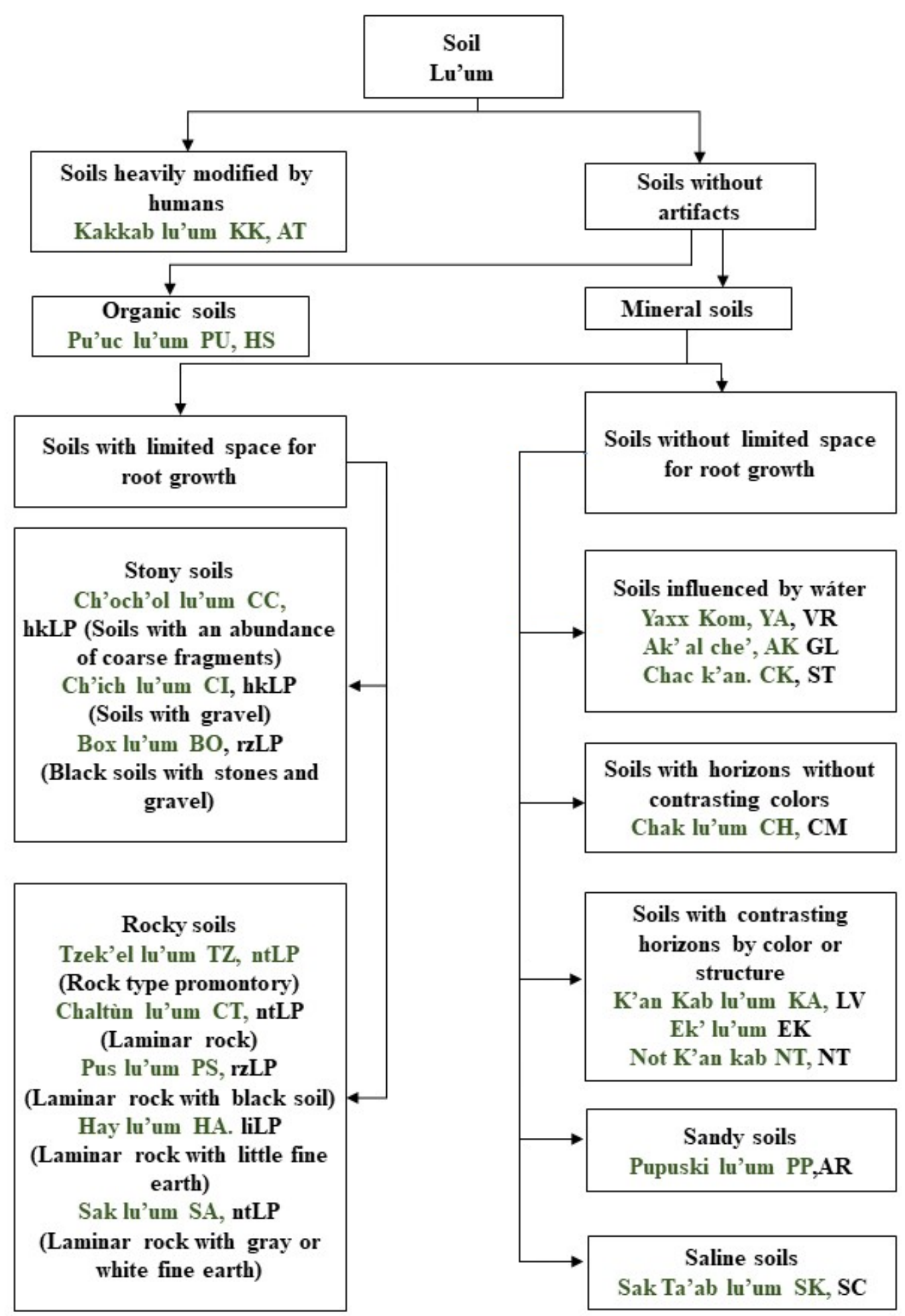


agnostic properties, such as heavily modified soils (Kakkablu'um), organic soils (Pu'uc lu'um) and mineral soils. Later two types of soil are described, with a lot or little space for the growth of the roots or in other words, shallow soils and deep soils.

There are two types of shallow soils, stony soils (Ch'och'ol lu'um, Ch'ich lu'um and Box lu'um) and rocky soils (Tzek'el lu'um, Chaltún lu'um, Pus lu'um, Hay lu'um and Sak lu'um).

Deep soils are of five types: Soils influenced by water, soils with horizons without contrasting colors, soils with contrasting horizons by color or structure, sandy soils and saline soils.

\subsection{MAYA SOIL GLASSIFICATION KEY}

The classication key for the Maya soils has been arranged in the following order: Maya name, Maya code, WRB code (Barrera, 1995).

\subsubsection{SOILS STRONGLY MODIFIED BY HUMANS}

Kakkablu'um, KK, TC. These soils are frequently black due to their high content of humified organic matter and ash. The organic matter comes from human feces, and the phosphorus content is high (Parnell et al., 2002; Holliday and Gartner, 2007). Hence, these soils are very fertile (phosphorous being the most limiting factor for agriculture in most of the peninsula). Soils containing ancient artifacts (such as ceramic shreds and ashes) are located in former home gardens and areas located within ancient Mayan cities (Parnell et al., 2002; Dahlin et al., 2007), and correspond partially to the group of Technosols (TC) in the WRB (2015).

\subsubsection{SOILS WITHOUT HUMAN ARTIFACTS}

\section{ORGANIC SOILS}

Pu'uc lu'um, PU, HS. These are black soils in wet areas normally covered by mangroves and with abundant organic matter derived from fresh and decomposing leaves, located in pseudo-lacustrine and lacustrine plains. Pu'uc lu'um (PU) are soils that correspond to the Histosol (HS) group of the WRB (2015). The horizon sequence is OeHa-C (Bautista et al., 2015). The thickness of the

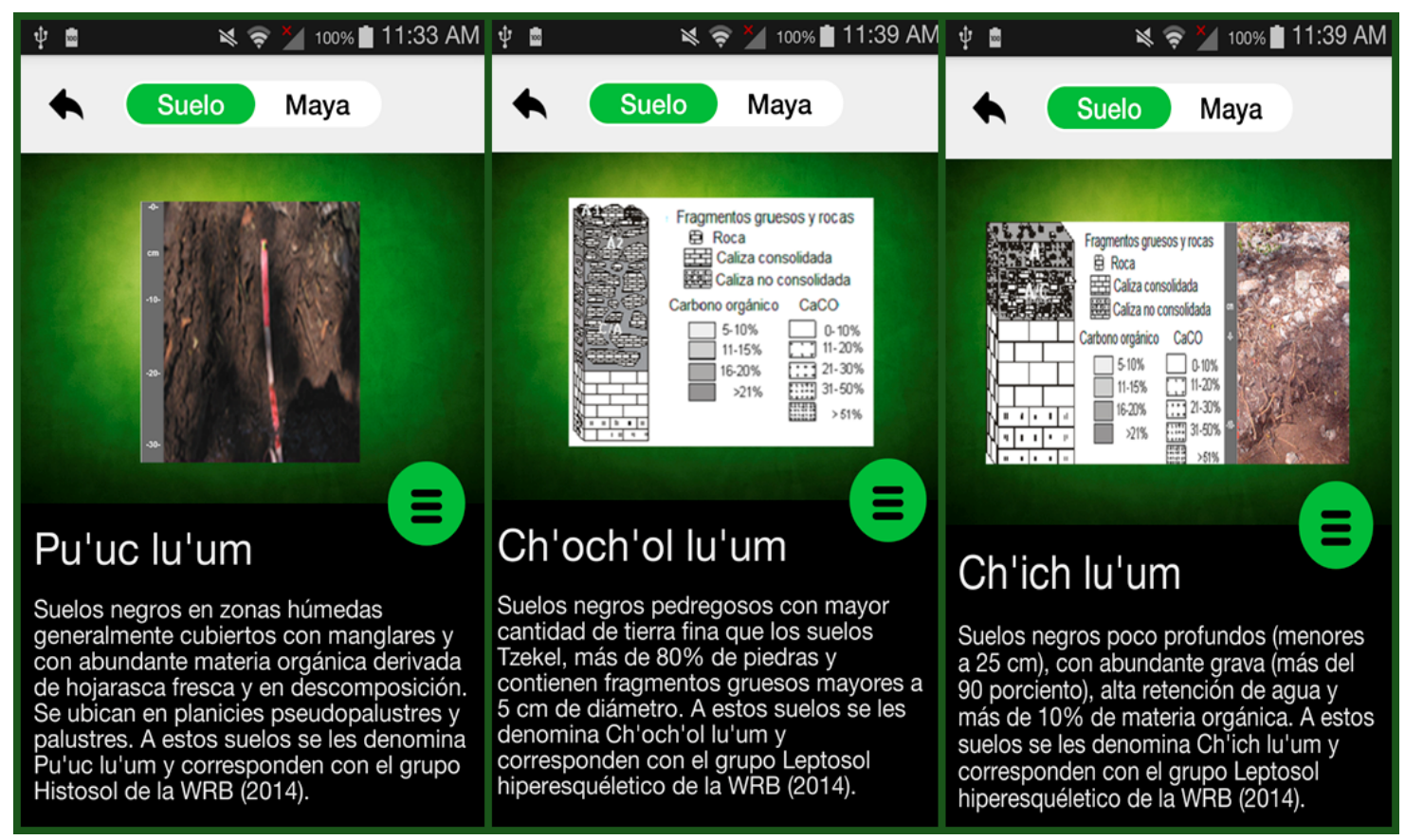

Figure 3 Organic soils Pu'uc lu'um, and rocky soils Ch'och'ol lu'um (stons), and Ch'ich Iu'um (gravel). The text inside the images is in the original language of the app. 


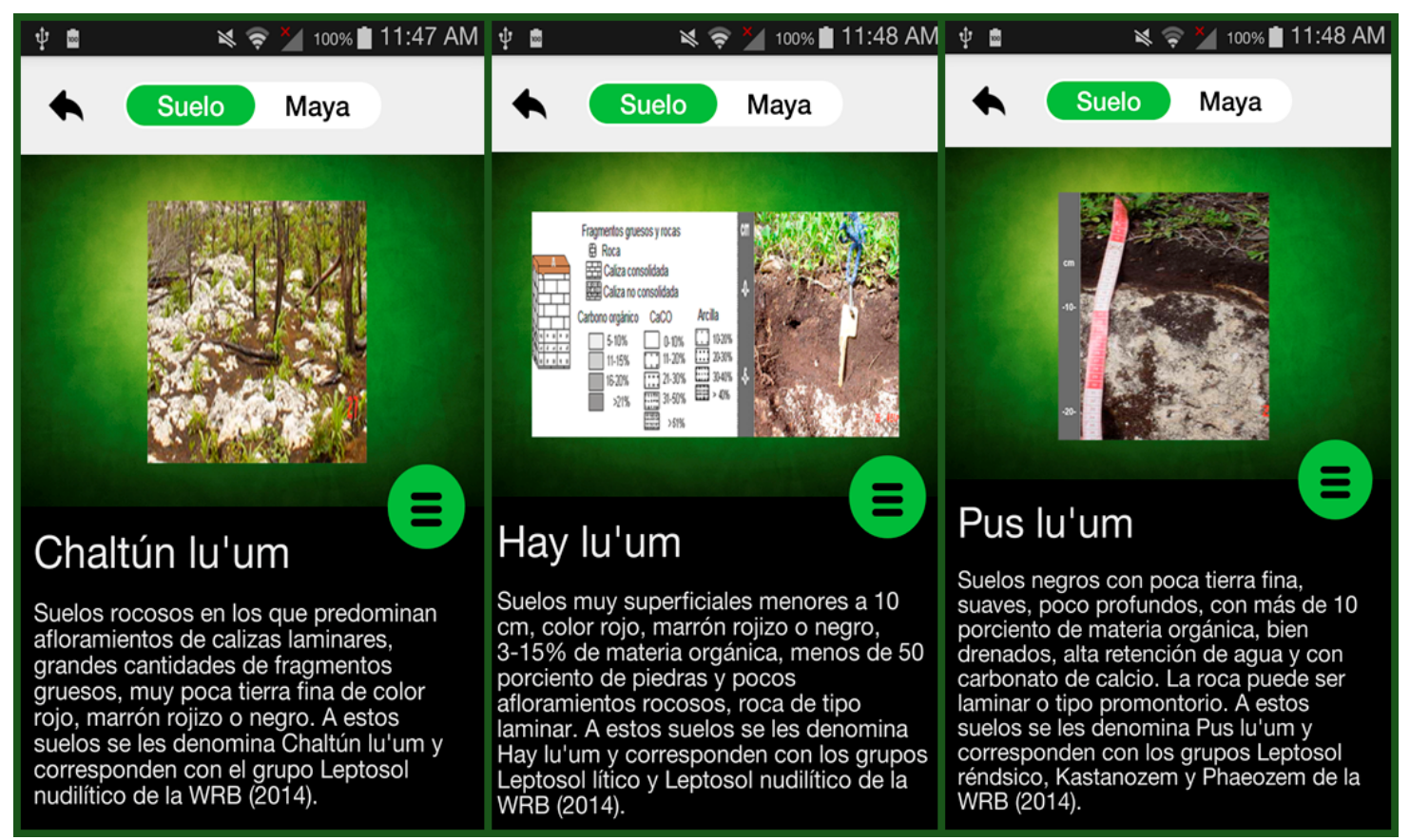

Rocky soils Chaltún lu'um, Hay lu'um, and Pus Iu'um. The text inside the images is in the original language of the app.

organic layer of the soil varies from 6.5 to $40 \mathrm{~cm}$, with a bulk density of 0.22 to $0.76 \mathrm{~g} / \mathrm{mL}$, and carbon content of up to $51.26 \%$ (Herrera, 2008) (Figure 3).

\section{MINERAL SOILS}

\section{1) SOILS WITH LIMITED SPACE FOR ROOTS}

\section{A) STONY SOILS}

Ch'och'ol lu'um, GG, hkLP (soils with abundant stones). Black stony soils with more fine soil than Tzek'el soils, over 80\% stone content, and the presence of rock fragments $>5 \mathrm{~cm}$ in diameter are termed Ch'och'ollu'um (CG), and correspond to the Hyperskeletic Leptosol (hkLP) soil group of the WRB (2015). The horizon sequence is Ahsk-C. The stones in the soil profile and the rocks at the base of the soil profile are limestone (Figure 4).

Ch'ich lu'um, Gl, hkLP (soils with gravel). Black shallow soils (less than $25 \mathrm{~cm}$ deep) with abundant limestone gravel $(>90 \%)$, over $10 \%$ organic matter, and high water retention, are termed
Ch'ich lu'um (CI). They correspond to the Hyperskeletic Leptosol (hkLP) soil group of the WRB (2015). The horizon sequence is Ahsk-R (Figure 4).

Box lu'um, BO, rzLP (black soils with stones and gravel). Black soils corresponding to the $\mathrm{Hy}$ perskeletic Leptosol group of the WRB (2015). These soils have a mixture of gravel and stones where none of these limestone fragments abundant $(\leq 80 \%$; Pérez, 1984). The horizon sequence is Ask- $R$.

\section{B) ROGKY SOILS}

Tzek'el lu'um, TZ, ntLP (mound-type rock). Black soils with scarce amounts of fine earth, rock outcrops forming mounds, and rocks $>25 \mathrm{~cm}$ in diameter. They correspond to the Nudilithic Leptosol (ntLP) group of the WRB (2015). Horizon sequence is A-R.

Chaltún lu'um, GT, ntLP (laminar rock). Rocky soils in which laminar limestone outcrops are dominant, with large amounts of thick frag- 


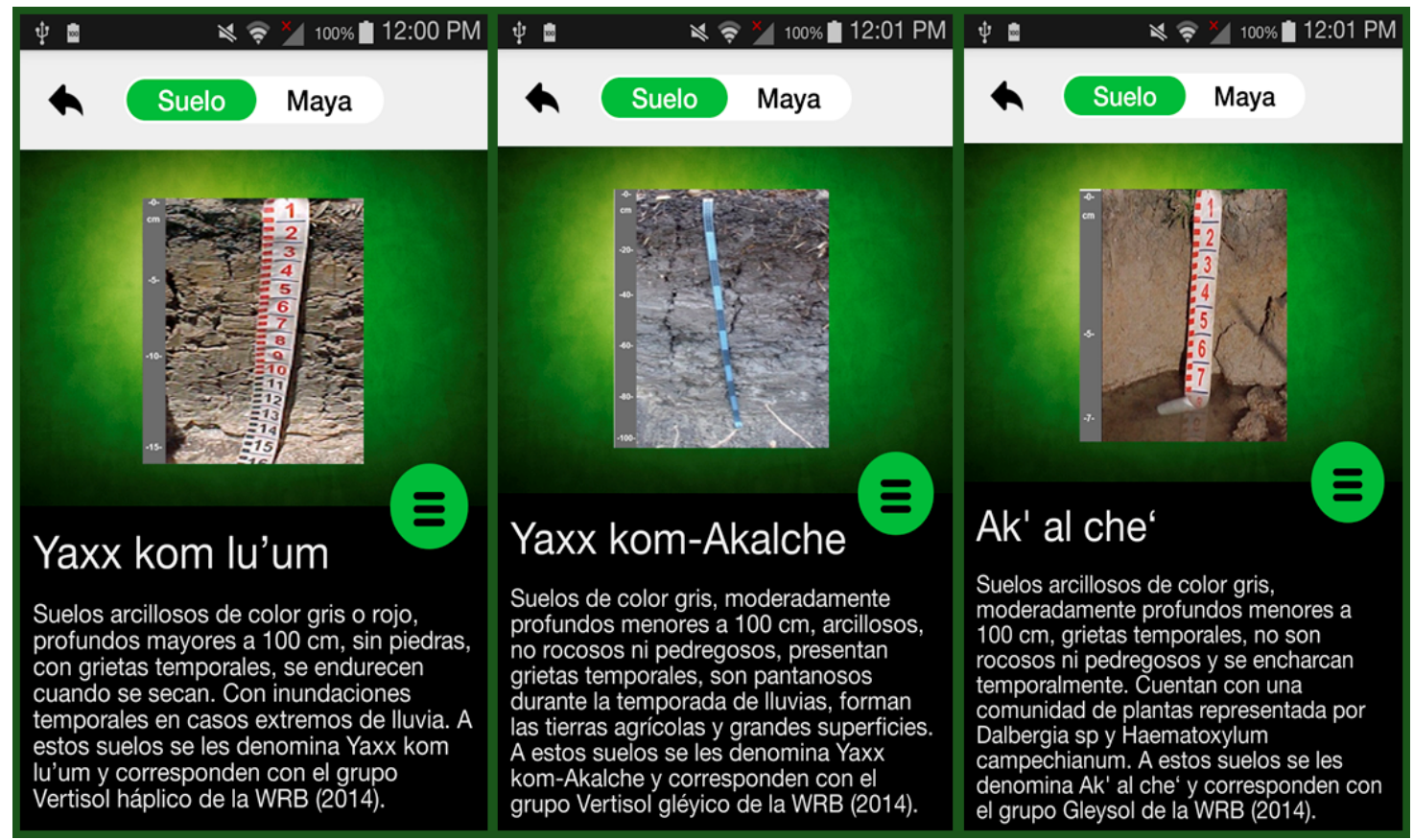

Soils influenced by water. The text inside the images is in the original language of the app.

ments, and scarce red, reddish-brown, or black-colored fine earth and correspond to the Nudilithic Leptosol (ntLP) group of the WRB (2015). Horizon sequence is A-R (Figure 4).

Pus lu'um, PS, rzLP (laminar rock with black soil). Black shallow soils with scarce fine earth, soft consistency, $>10 \%$ organic matter, well drained, high water retention, and contain calcium carbonate. The rock can be laminar or form limestone mounds. PS correspond to the Rendzic Leptosol (rzLP), Kastañozem, and Rendzic Phaeozem groups of the WRB (2015). The horizon sequence is Ah-R (Figure 4).

Hay lu'um, HA, liLP (laminar rock with scarce soil). Red, reddish-brown, or black-colored shallow soils ( $<10 \mathrm{~cm}$ deep), with $3-15 \%$ organic matter, $<50 \%$ rocks, and scarce outcrops of laminar limestone rock. These soils correspond to the Lithic Leptosol and Nudilithic Leptosol groups of the WRB (2015). The horizon sequence is A-R (Figure 4).
Sak lu'um, HA, liLP (laminar rock with scarce soil). Light gray, very shallow $(3-17 \mathrm{~cm}$ deep) clayey-sandy soils with moderate drainage, calcareous, and with a C horizon (Beach, 1998). They correspond to the Lithic Leptosol (liLP) group of the WRB (2015). The horizon sequences Ak-Ck-R.

\section{2) SOILS WITHOUT SPAGE LIMITATIONS FOR ROOT GROWTH}

\section{A) SOILS INFLUENGED BY WATER}

Yaxxkom lu'um, YA, haVR. Grey to red color, deep (>100 cm deep) clayey soils, without stones, exposing desiccation-induced cracks, and hardening when drying. Temporary flooding in cases of extreme precipitation. Termed Yaxxkom lu'um (YK). They correspond to the Haplic Vertisol (haVR) group of the WRB (2015). The horizon sequence is A-Bi-C (Figure 5).

Yaxxkom-K'ankablu'um, Y-K, haVR. Red color, moderately deep (>100 cm deep) clayey soils, 
without stones, features desiccation cracks, hardens when dry, and is usually fertile. Temporary flooding occurs in cases of extreme precipitation. Termed Yaxxkom- K'ankab lu'um (YK). They correspond to the Haplic Vertisol (haVR) group of the WRB (2015). The horizon sequence is A-Bi-C (Figure 5).

Yaxxkom-Ak'alche', Y-A, glVR. Gray colored, moderately deep (>100 cm deep) clayey soils without rocks or stones, with desiccation cracks, and swampy during the rainy season. These soils form cropland over large surfaces and correspond to the Stagnic Vertisol (glVR) group of the WRB (2015). The horizon sequence is A-Bl-Cl.

Ak' al che' lu'um, AK, ST. Gray colored, moderately deep ( $<100 \mathrm{~cm}$ deep) clayey soils, with desiccation cracks, without rocks and stones, and with temporary flooding during storms. Covered by a plant community represented by Dalbergia sp. and Haematoxylum campechianum. These soils correspond to the Stagnosols (ST) group of the WRB (2015). The horizon sequence is A-Bg-Cr (Figure $5)$.
Chack'an lu'um, GK, ST. Clayey soils, red colored on the surface, with reducing conditions in the upper portion, moderately deep $(<100 \mathrm{~cm}$ deep), with desiccation cracks, without rocks or stones, and with temporary flooding. These are termed Chack'an (CK) and correspond to the Stagnosols (ST) group of the WRB (2015). The horizon sequence is $\mathrm{Ag}-\mathrm{Bg}-\mathrm{C}$.

\section{B) SOILS WITHOUT GONTRASTING GOLORS BETWEEN HORIZONS}

Chak lu'um, GH, GM. Red or reddish-brown soils with $<5 \%$ organic matter, slightly stony, and without rocks. The horizon sequence is $\mathrm{A}-\mathrm{Bw}-\mathrm{C}$ (Figure 6). When shallow ( $<25 \mathrm{~cm}$ deep), these soils are termed Ma'taan Chak lu'um $(\mathrm{CH})$ and correspond to the Haplic Leptosol group of the WRB (2015). With a moderate depth $(25-50 \mathrm{~cm})$ they are termed Taan taan Chak lu'um $(\mathbf{C H})$ and correspond to the Cambisols group of the WRB (2015). With a depth of $>100 \mathrm{~cm}$ they are termed Hach taan Chak lu'um $(\mathrm{CH})$ and correspond to the Cambisols group of the WRB (2015).

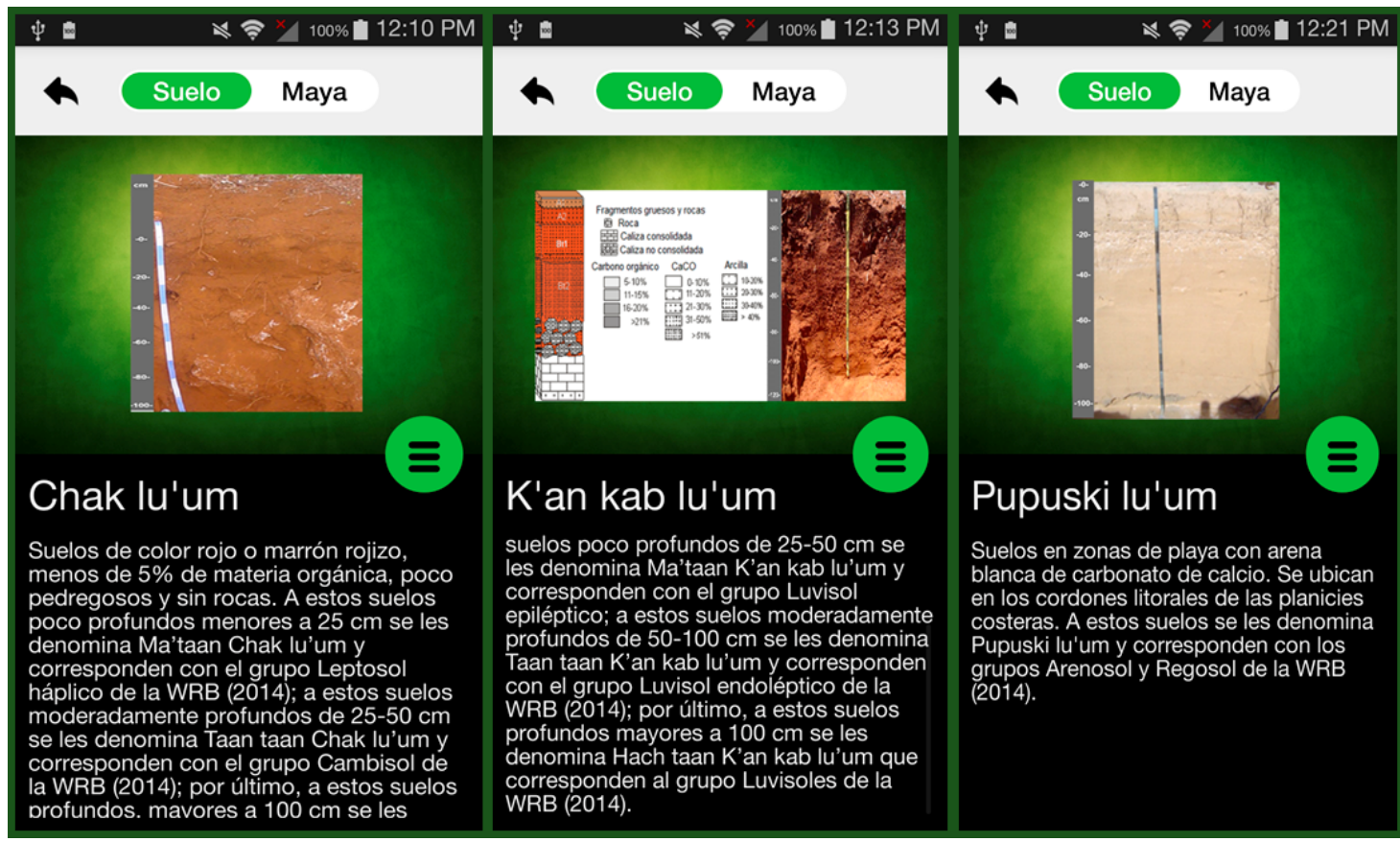

Figure 6 Soils without contrasting colors between horizons (Chak lu'um), soils with contrasting colors between horizons (K'an kab Iu'um), and sandy soils (Pupuski lu'um). The text inside the images is in the original language of the app. 


\section{G) SOILS WITH GONTRASTING GOLORS BETWEEN HORIZONS}

K'ankab lu'um, KA, LV. Soils with red or reddish-brown topsoil over a yellow subsurface layer, $<5 \%$ organic matter, without rocks or stones, they harden when dry, however desiccation cracks are not formed (Dunning, 1992; Dunning and Beach, 2004; Jensen et al., 2007). When these soils are moderately shallow $(25-50 \mathrm{~cm}$ deep) they are termed Ma'taan K'ankab lu'um (KA) and correspond to the Epileptic Luvisol group of the WRB (2015). When moderately deep (50-100 cm), they are termed Taantaan K'ankab lu'um (KA) and correspond to the Edoleptic Luvisol group of the WRB (2015). At a depth of $>100 \mathrm{~cm}$, they are termed Hach taan K'ankab lu'um and correspond to the Luvisols group of the WRB (2015). The horizon sequence is A-Bt-C (Figure 6).

$\boldsymbol{E} \boldsymbol{k}^{\prime} \boldsymbol{l} \boldsymbol{u}^{\prime} \boldsymbol{u m}, \mathbf{E K}, \mathbf{L V}$. Soils that are black on the surface, with a yellow or red subsurface layer containing more organic matter $(>5 \%)$ than the $K^{\prime}$ ankab lu'um soils, and without rocks or stones. Termed Ek' lu'um (EK); they correspond to the Phaeozems and Luvisols groups of the WRB (2015). The horizon sequence is A-Bt-C.

Not K'ankab lu'um, NK, NT. Intensely red-colored soils with $<5 \%$ organic matter, aggregated and very stable, neither rocky nor stony. Termed Not K'ankab lu'um (NK); they correspond to the Nitisols group of the WRB (2015). The horizon sequence is $\mathrm{A}-\mathrm{Bw}-\mathrm{C}$.

\section{D) SANDY SOILS}

Pupuski lu'um, PP, AR. Beach-area soils with calcium carbonate sand located on offshore cays next to coastal plains. Termed Pupuski lu'um (PP); they correspond to the Arenosols group of the WRB (2015). The horizon sequence is A-C.

\section{E) SALINE SOILS}

Sak Ta'ablu'um lu'um, SK, SC. Saline soils in beaches and coastal plains. They correspond to the Solonchaks group of the WRB. Interruption of water flow causes salts to accumulate on the surface, which makes these soils bluish-white (in Spanish, blanquisales).

\subsection{PHOTOGRAPHS OF SOIL PROFILES WITH MAYA AND TEGHNICAL NAMES}

The app has twenty photographs of soil profiles. The user can compare a soil profile in the field to the image shown by the app to get an idea of what kind of soil it is, or to which group of soil it belongs.

The user touches the image of the soil profile and the app displays the name with either the Maya soil classification or the soil group classification according to the WRB.

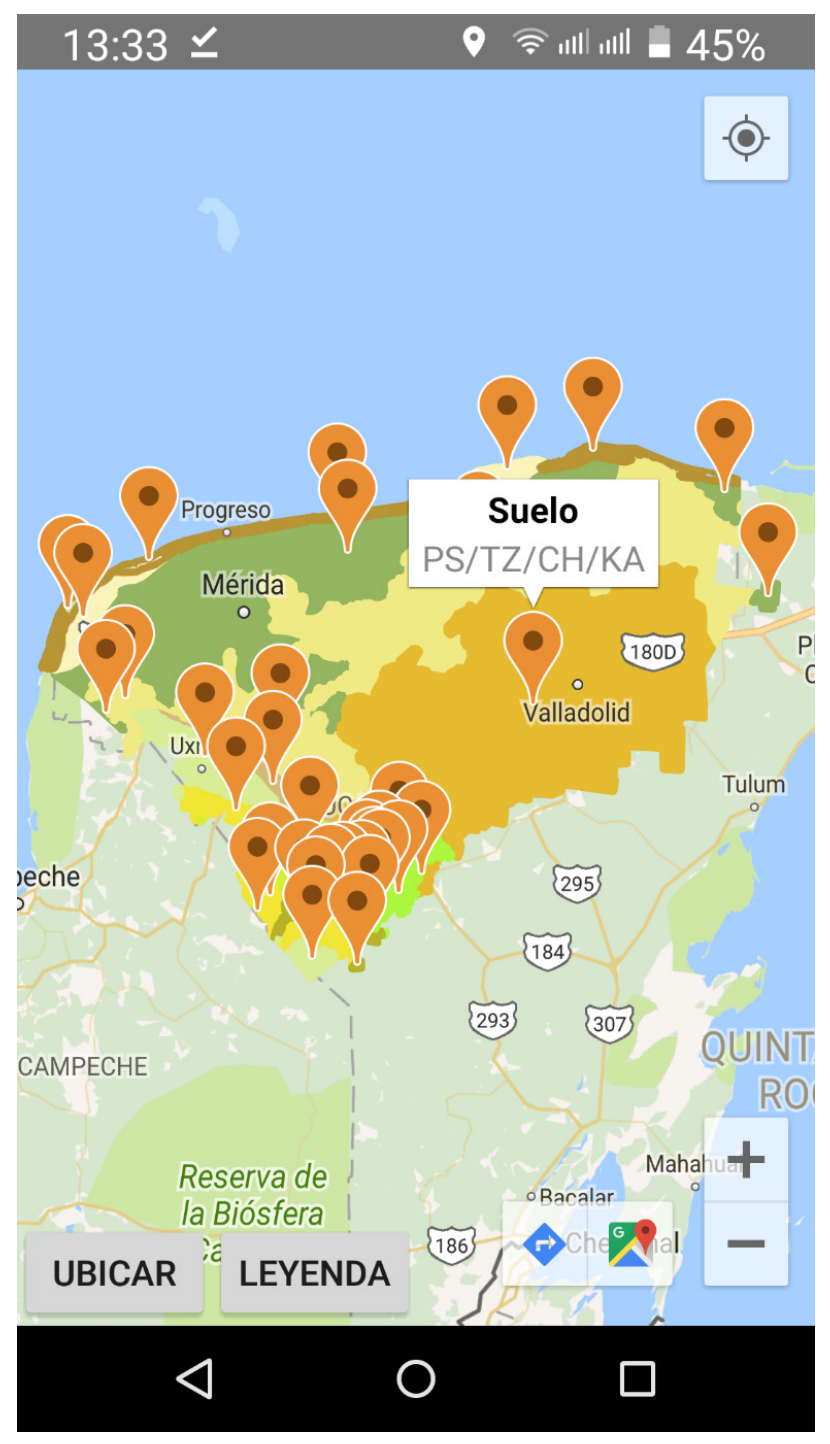

Figure 7 State of Yucatán soil classification map overlaid in Google Maps. The text inside the images is in the original language of the app. 


\subsection{SPATIAL DISTRIBUTION OF SOILS IN THE STATE OF YUCATÁN, MEXICO}

Two functions of the app address this issue. The first is the soil map, which contains two legends: the Maya soil classification and the technical names according to the WRB. The second function determines through GPS the precise location of the user and the soils associated with that location according to both classification schemes.

By means of the smartphone's GPS, any site within the state of Yucatán can be located both on Google Maps and on a soil classification map (Figure 7). This allows the user to know which soils are associated with the site. By means of an altimeter and the soil classification map, the user can identify the Maya soil class present at the location. It would be necessary to increase the accuracy of soil maps to a scale of 1:25000, and in sites with high agronomic importance, to a scale of 1:10000 or 1:5000, to help improve agricultural and forestry soil management practices. Detailed soil maps are also needed for environmentally important areas to help in issues pertaining to water quality and ecosystem conservation; they can also be useful for landscape conservation in tourist areas.

\section{Conclusions}

The Maya knowledge of soils is free from the three main limitations pointed out by soil scientists: (1) Maya soil classification reaches beyond the surface horizon, including subsoil properties (e.g, Kankab means yellow under); in some cases, ecosystemic terms indicate processes, topography, and plant-cover factors (e.g., A'kalche' and Petén); (2) Maya soil nomenclature can be organized in a classification system similar to WRB soil classification system, as shown in this article; and (3) Maya soil knowledge goes beyond farmers' plots and can be used for making state or regional soil maps, as also shown here. Further yet, the international soil classification groups Hyperskeletic Leptosols and Nudilithic Leptosols were created and adopted by acknowledging Maya soil nomenclature.

We expect that the use of the Maya Soil Classification app will motivate users to suggest the inclusion of many soil terms to improve soil classification.

It is expected that the use and improvement of soil maps using the Maya soil classification in combination with the international soil classification system will result in better agricultural productivity, and in effective conservation of ecosystems and the environment.

The use of soil information in agronomic and ecological studies is extremely scarce in Yucatán, because, among other factors, there are less than ten soil scientists in the state. However, the app "Maya soil classification" already has more than a hundred users and we hope that this number will increase with the passage of time.

\section{Acknowledgments}

The authors acknowledge financial aid from Scientific Knowledge In Use, http://www.actswithscience.com. Francisco Bautista acknowledges financial support from Dirección General de Asuntos del Personal Académico de la Universidad Nacional Autónoma de México for a sabbatical leave at the Centro de Edafologia y Biologia Aplicada del Segura del Consejo Superior de Investigaciones Científicas de España.

\section{References}

Balaguera, Y.D., 2013, Metodologías ágiles en el desarrollo de aplicaciones para dispositivos móviles. Estado actual: Revista de Tecnología, 12(2), 111-124.

Barrera, A., 1995, Diccionario Maya: mayaespañol, español-maya: Mexico City, Mexico, Porrúa, 1418 p. 
Bautista, F., Palacio, G., 2012, Península de Yucatán, in Krasilnikov, P., Jiménez-Nava, F.J., Reyna-Trujillo, T., García-Calderón, N.E., (eds.), Geografía de Suelos en México: Mexico City, Mexico, Prensas de Ciencias, Universidad Nacional Autónoma de México, 355-406.

Bautista, F., Zinck, J.A., 2010, Construction of an Yucatec Maya soil classification and comparison with the WRB framework: Journal of Ethnobiology and Ethnomedicine, 6(7), doi:10.1186/1746-4269-6-7.

Bautista-Zuñiga, F., Jiménez-Osornio, J., Navarro-Alberto, J., Manu, A., Lozano, R., 2003, Microrelieve y color del suelo como propiedades de diagnóstico en Leptosoles cársticos, México: Terra Latinoamericana, 21(1), 1-11.

Bautista-Zuñiga, F., Estrada-Medina, H., Jiménez-Osornio, J., González-Iturbe, J., 2004, Relación entre relieve y unidades de suelo en zonas cársticas de Yucatán: Terra Latinoamericana, 22(3), 243-254.

Bautista-Zuñiga, F., García, J., Mizrahi, A., 2005a, Diagnóstico campesino de la situación agrícola en Hocabá, Yucatán: Terra Latinoamericana, 23(4), 571-580.

Bautista, F., Díaz-Garrido, S., Castillo-González, M., Zinck, J.A, 2005b, Spatial heterogeneity of the soil cover in the Yucatán karst: comparison of Mayan, WRB, and numerical classifications: Eurasian Soil Science, 38(suppl 1), 81-88.

Bautista, F., Zinck, A. J., Cram, S., 2010, Los suelos de Latinoamérica: retos y oportunidades de uso y estudio, México: Boletín del Sistema Nacional de Información Estadística y Geográfica, 2(3), 93-142.

Bautista, F., Maldonado D., Zinck, A.J., 2012, La clasificación maya de suelos: Ciencia y desarrollo, 260, 64-70.
Bautista, F., Frausto, O., Ihl, T., Aguilar, Y., 2015, Actualización del mapa de suelos de Yucatán México: enfoque geomorfopedológico y WRB: Ecosistemas y Recursos Agropecuarios, 2(6), 303-315.

Beach, T., 1998, Soil constraints on Northwest Yucatán, Mexico: Pedoarchaeology and Maya subsistence at Chunchucmil: Geoarchaeology, 13(8), 759-791.

Canós, J., Letelier, P., Penadés, M., 2003, Metodologías ágiles en el Desarrollo de Software, in Letelier, P., Sánchez-López, E.A., (eds.), Metodologías Ágiles en el Desarrollo de Software: Alicante, España, Grupo ISSI, 1-8.

Dahlin, B.H, Jensen, G..T., Terry, R.E., Wright, D.R., Beach, T., 2007, In search of an ancient Maya market: Latin American Antiquity, 18(4), 363-384.

Duch, J., 2005, La nomenclatura maya de suelos: una aproximación a su diversidad y significado en el sur del estado de Yucatán: Revista de Geografía Agrícola, 34, 55-74.

Dunning, N., 1992, Lords of the hills: ancient maya settlement in the Puuc region, Yucatán, México: Madison, USA, Prehistoric Press, Monographs in World Archaeology, 15, 303 p.

Dunning, N., Beach, T., 2004, Fruit of the luum: lowland maya soil knowledge and agricultural practices: Mono y conejo, Journal of the Mesoamerican Archaeological Research Laboratory, The University of Texas at Austin, 2, 3-15.

Ettema, C.H., 1994, Indigenous soil Classifications: What is their structure and function, and how do they compare to scientific soil classifications? (on line): Athens, GA, USA, University of Georgia, available in <http:// www.css.cornell.edu/faculty/dgr2/Docs/ Misc/IntroToEthnopedology.pdf> consulted on November 20, 2018. 
Holliday, V.T., Gartner, G., 2007, Methods of soil $\mathrm{P}$ analysis in archaeology: Journal of Archaeological Science, 34(2), 301-333.

Herrera, J., 2008, Diagnóstico ambiental de dos ecosistemas costeros del Estado de Yucatán con base en la fijación de carbono del suelo: Mérida, Mexico, Universidad Autónoma de Yucatán, Bachelor thesis, 57 p.

International Union for Soil Sciences Working Group World Reference Base for Soil Resources (IUSS-WRB), 2015, Base referencial mundial del recurso suelo 2014, Sistema internacional de clasificación de suelos para la nomenclatura de suelos y la creación de leyendas de mapas de suelos: Rome, Italy, Food and Agriculture Organization of the United Nations, Informes sobre recursos mundiales de suelos, 106, 205.

Jensen, C.T., Moriarty, M.D., Johnson, K.D., Terry, R.E., Emery, K.F., Nelson, S.D., 2007, Soil resources of the Motul de San José Maya: correlating soil taxonomy and modern Itzá Maya soil classification within a classic Maya archaeological zone: Geoarchaeology, 22(3), 337-357.
Krasilnikov, P., Tabor, J., 2003, Perspectives on utilitarian ethnopedology: Geoderma, 111 (34), 197-215.

Ortiz, G., Gutiérrez-Castorena, C., LiconaVargas, A., Sánchez-Guzmán, P., 2005, Contemporary influence of indigenous soil (land) classification in México: Eurasian Journal of Soil Science, 38, 89-94.

Parnell, J.J., Terry, R.E., Nelson, Z., 2002, Soil chemical analysis applied as an interpretive tool for ancient human activities in Piedras Negras, Guatemala: Journal of Archaeological Science, 29(4), 379-404.

Pérez, J., 1984, Caracterización y utilización de la clasificación maya de suelo en el municipio de Oxcutzcab Yucatán: Chapingo, Mexico, Universidad Autónoma de Chapingo, Bachelor thesis, 138 p.

Pool, L., Hernández, E., 1987, Los contenidos de materia orgánica de suelos en áreas bajo el sistema agrícola de roza, tumba y quema: importancia del muestreo: Terra, 5, 81-92.

Sweetwood, R., 2008, The maya footprint: soil resources of Chunchucmil, Yucatán, México: Utah, USA, Brigham Young University, Master of Science thesis, $77 \mathrm{p}$. 